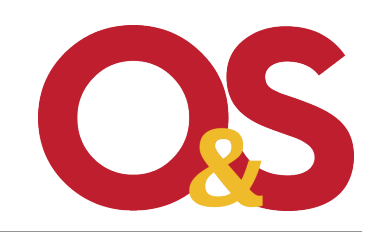

Revista Organizações \& Sociedade

2020, 27(92), 132-151

\title{
Identity, Consumption and Ontological Security: Trying to Live on the Edge of the Aesthetic Norm
}

(1) The Author(s) 2020

DOl 10.1590/1984-9270927

ISSN 1984-9230

\author{
Identidade, consumo e segurança ontológica: tentando viver à margem da \\ normatividade estética
}

www.revistaoes.ufba.br

NPGA, Escola de Administracãa

Universidade Federal da Bahia

Received: 24/09/2017

Tânia Maria de Oliveira Almeida Gouveiaa

Accepted: 11/04/2019

Eduardo André Teixeira Ayrosa ${ }^{b}$

aUniversidade do Estado do Rio de Janeiro, Rio de Janeiro, RJ, Brasil

Universidade Positivo, Curitiba, PR, Brasil

\begin{abstract}
The body is an important element in identity management, and its transformations can, to a greater or lesser degree, be related to a reflexive project. Such identity projects are closely related to marketing stimuli, either aligning with or resisting its contents and values to keep a stable and secure identity narrative, building what Giddens $(1984 ; 1991)$ calls ontological security. The aim of this study is to understand how body-related narratives and practices interact with market stimuli to produce a coherent and ontologically secure "self" that is capable of deviating from the dominant aesthetic standard. Discourse analysis of data indicated four instances that describe how such interaction happens: "struggles with self-demands", "extreme disciplinary routines", "self-confidence building", and "partitions of the body". Markets provide discursive objects that individuals use to mitigate their problems with deviating from the aesthetic norm, forming coherent narratives and ensuring their ontological security.
\end{abstract}

Keywords: Identity; Consumption; Ontological Security.

\section{Resumo}

O corpo é um elemento importante no gerenciamento de identidades e suas transformações podem estar relacionadas, em maior ou menor grau, a um projeto reflexivo. Tais projetos de identidade estão intimamente relacionados a estímulos de marketing, seja alinhando ou resistindo a seus conteúdos e valores para manter uma narrativa identitária estável e segura, construindo o que Giddens $(1984 ; 1991)$ chama de segurança ontológica. 0 objetivo deste estudo é entender como as narrativas e práticas relacionadas ao corpo interagem com os estímulos do mercado para produzir um "eu" coerente e ontologicamente seguro, capaz de desviar-se do padrão estético dominante. A análise de discurso dos dados indicou quatro instâncias que descrevem como essa interação acontece: "lutas com demandas sobre si", "rotinas disciplinares extremas", "construção da autoconfiança" e "partições do corpo". Os mercados fornecem objetos discursivos que os indivíduos usam para mitigar seus problemas, desviando-se da norma estética, formando narrativas coerentes e garantindo sua segurança ontológica.

Palavras-chave: Identidade; Consumo; Segurança Ontológica. 


\section{Introduction}

I think I'm a bit of a freak... Just look at my nose: it's crooked. See? My eyes are deep-set with dark circles ... I can talk about it - no problem. My ear is deformed... well, not that deformed, but... it's not normal. And this eye isn't right ... it's about ten degrees off from the other one. My nose has a deviation, and that's a fact; no joke. (...) And I have big ears - they used to call me Dumbo; damn! (Daniel, 24)

This self-description of Daniel, one of the informants in this study, bluntly highlights his concern with his appearance, or rather, the way his appearance meets the prevailing aesthetic norms. Appearance and essence have been dangerously close for a long time. An ad by "Creme de Alface Brilhante" (Lettuce Cream for Radiant Skin) published in the January 11, 1958 edition of the magazine "O Cruzeiro" (p. 32) says: "Beauty is an obligation. Nowadays, you don't have to be ugly if you don't want to". There are, nowadays, forms of access, concession or resistance that did not exist in 1958. Conceding to and resisting the aesthetic norm involves the narratives, practices and specific disciplinary routines that are the main objectives of this study: consumption practices related to self-care, and the reflexivity of the individual-consumer as revealed in coherent narrative identities that guarantee their holder a sense of ontological security.

The body is an important symbolic element in one's identity management, and its transformations can more or less be related to a reflexive project (Safatle, 2004). By studying practices of transforming the body, from the least definitive, such as dieting and exercising, to the most invasive, such as tattoos and implants, Featherstone (2000) states that individuals have a sense of control over their body and the signs of identity that it indicates. However, it is subject to a change in rhetoric spread by the media, which prompts them to pursue ideals of youth and beauty, in a scenario where bodies that used to be covered up are now widely exposed. Featherstone $(2000$, p. 2 ) explains "... that within consumer culture the body has always been presented as an object ready for transformation".

Propositions about the consumer culture theory presented by authors such as Arnould and Thompson (2005), Belk (1988), Featherstone (2000), Holt (1997), McCracken (2010), and Thompson and Hirschman (1995) indicate that consumers' narrative identities are closely related to marketing. If, on the one hand, these narratives give consumers the feeling that they are making choices and that they are responsible for them, on the other hand, they reveal "ready-to-wear" models for beauty, harmony and happiness proffered (often quite aggressively) by marketing institutions. Regarding this aspect, Thompson and Hirschman (1995) point out that the desire to achieve the idealized appearance is the result of a multibillion-dollar investment by the industry to sell its products and services. These authors' poststructuralist viewpoint indicates that identity development is directly connected to consumers. Arnould and Thompson (2005, p. 871) basically agree with this proposition and indicate that, even though individuals are looking for "... personally edifying goals through these consumer positions", they are also aligning their identities with global imperatives.

The theme "identity" has great appeal in the humanities and social sciences. Identities are often defined in terms of the "self." Authors such as Bauman (2005) and Hall (2011) describe this relationship as being weak, conceiving the self as fragmented into several different concepts of identity, or different identity narratives. According to this concept, the notion that coordinates individuals' actions regarding their body is also weak. Bauman (2005) agrees with the idea that individuals are subjected to marketing tyranny, and that their body is built by regulatory forces.

On the other hand, authors such as Giddens $(1984,1991)$ believe in individuals' reflexive capacity for action in relation to themselves and their body. Although he does not rule out the influence of demands of the environment, Giddens (1984) argues that control over the body is essential for individuals to preserve what he calls an ontological security (Giddens, 1984, p. 375), defining it as "... confidence or trust that the natural and social worlds are as they appear to be, including the basic existential parameters of self and social identity." 
Giddens' (1984) remarks indicate that confident individuals face the pressures of social life without anxiety, while those who are "... ill-equipped to face these pressures succumb and go under" (Giddens, 1984, p. 63). Those who feel at least a bit secure about their life conditions - including managing their body - are " $\ldots$ able to sustain a minimal sphere of control and self-esteem" (Giddens, 1984, p. 63), sticking to their routine with a greater or lesser degree of autonomy.

In this paper, we have adopted the perspective in line with the strongest reasoning in Giddens' ideas. Believing that discourses emanating from the market affect the way individuals see and relate to their own bodies, the aim of this study is to understand how body-related narratives and practices interact with marketing incentives in order to produce a coherent and ontologically secure self that is capable of deviating from the dominant aesthetic norm.

\section{Bibliographical review}

Identity

In sociology, as well as in social psychology, identity tends to be seen as relationally linked to dispositions, descriptions and judgments that we and others make about ourselves. As Jenkins (2008) points out, psychology tends to prioritize identity as an individual trait, whereas most sociologists tend to adopt a collectivist viewpoint that tends to emphasize the narratives and practices that shape social groups, which give them a sense of community, no matter how indefinite it may be. Jenkins (2008) adopts a perspective in which individual and community aspects share one and the same narrative universe. From his perspective, these aspects are routinely intertwined with each other: individual and collective identities exist only in interaction, and are produced and reproduced in a similar way; any theorizing about identification processes must accommodate both "in equal measure" (p. 38). This approach seems to be quite popular in the area of consumer behavior and studies on consumption, especially in works that are interpretative, such as those by Schau (2000), Thompson and Holt (2004), and Luedicke, Thompson, and Giesler (2010).

Charles Taylor's ideas are particularly important in this line of reasoning. Taylor (1992) understands identity as answers to the question "Who am I?" not in the legal, demographic or genealogical sense, but in the sense of the individual's standing:

My identity is defined by the commitments and identifications which provide the frame or horizon within which I can try to determine from case to case what is good, or valuable, or what ought to be done, or what I endorse or oppose. In other words, it is the horizon which I am capable of taking a stand. (Taylor, 1992, p. 27).

Such a statement imposes moral responsibility on individuals regarding the practices or narratives, in which they are engaged. There is only identity within the ambit of "webs of interlocution" (Taylor, 1992, p. 36).

Identity and consumption

Consumption can be seen under an economic bias, from a cultural perspective or through a dialogue between these two standpoints, which is an indicator of the complexity of the subject (Lunt, 1995). We follow the view that consumption is, according to Slater (2001, p. 17), "always and everywhere a cultural process"; that goods possess cultural meanings that the consumer uses to, in McCracken's words (2010, p. 11), "... cultivate ideals, create and sustain lifestyles, construct notions of self, and create (and survive) social change." 
Schouten and McAlexander (1995), as well as several other authors (e.g. Arnould \& Thompson, 2005; Thompson, 2014; Gabriel, 2015), indicate that, for better or worse, consumption plays an important role in the construction and reconstruction of the individual's identity. This correlation between consumption and identity is due, among other reasons, to the dwindling of traditional modes of identity construction, such as family, religion and community. Gabriel (2015) states that if identity has served organizational studies theorists as a powerful frame to view phenomena such as embracing organizational narratives and values that help them to exceed their tasks, for consumer researchers, "it has proven manna from heaven, ... where every consumer desire, whim or impulse can be readily viewed as part of a self striving towards identity" (Gabriel, 2015, p. 26-27). In their influential paper where they forge the "Consumer Culture Theory" (CCT from now on) denomination, Arnould and Thompson (2005) list "consumer identity projects" as one of the four research programs in CCT: "Consumer culture theory concerns the coconstitutive, coproductive ways in which consumers, working with marketer-generated materials, forge a coherent if diversified and often fragmented sense of self" (Arnould \& Thompson, 2005, p. 871). Dittmar (2011) corroborates the idea that identity is constructed through the acquisition and consumption of goods, and is no longer attributed to or inherited by the individual. One example of such process is the account by Lamont and Molnar (2001) of how black consumers use goods to shape their ethnic identity, or Pereira and Ayrosa's (2012) description of how gay men use consumption to manage their gender identity.

There is convergence in relation to the idea that not only identity, but also social and cultural values are defined under parameters of consumption. McCracken (2010); Ostergaard, Fitchett and Jantzen (1999); Barbosa and Campbell (2007); Arnould and Thompson (2005) and Belk (1988) discuss the subjective aspects relevant to the consumption process, whose meanings may vary according to the market and its cultural context, and which directly impact social constructions and the structuring of subjectivities and identities.

From the principle that possessions strongly relate with the self, one may question what causes the individual to choose this or that object - or, thinking about identity, to define and show him/herself to the other based on this or that product. Under the inspiration of Slater (2001, p. 40), who asks whether the consumer is a hero or an idiot, we question who defines what kind of reason guides the individual in his or her identity construction: an objective individual reason or a communitarian and subjective reason? Or both, in a sign of market action and, at the same time, reflective capacity of the individual to define his own identity with what's in store? In this respect, Slater $(2001$, p. 40) argues that, on the one hand, modern thinking tends to see the consumer as a "schizoid character", as a "ridiculous figure", "a muggle or cultural fool". However, on the other hand, the consumer is reputed to be a "hero of modernity (...) because only the needs defined by himself can legitimize economic and social institutions". From this polarization, there are those who claim that the market is powerful and manipulative - sometimes dramatically, as if evil (the market) is overcoming the good (the individual) - and on the other hand, those who, at the risk of approaching naivety or over-optimism, argue that the consumer is free.

Building on the consumer agency, Firat and Venkatesh (1995) propose that, in postmodernism, consumption has emancipatory potential. The consumer can choose, give up, surprise, risk, disagree. To confirm this proposition, the authors mention the diversity of lifestyles that can exist in the same family, in which its members have different experiences of consumption, being autonomous in choosing what they prefer. On the other hand, Slater (2001, p. 100) analyzes consumption as a "social pathology intrinsically linked to modernity", which manufactures fixed identities and values as if they were commodities, with no authentic, traditional, lasting social values. In this case, "modern identity is best understood through consumer ideas.... Self is not an inner perception of authenticity, but a calculable situation of survival and social success" (Slater, 2001, p. 87).

Campbell (2001) states that consumption stimulates a desire that is not exhausted, which is renewed with each purchase, which means that we always want something we do not have. He attributes to the media, producers and market researchers the role of manipulating consumers who are passively convinced that they 
need a product. Mass media, according to Campbell (2001, p. 71) "function as a hypodermic needle to inject a particular message into their audience. In this case, what is injected into the 'bloodstream' of consumers is the 'need' for a specific product or service." Dittmar (2011), for example, believes that celebrities who populate the mass media are able to influence who the consumer wants to be or who they want to look like. In this sense, the possession of material goods would be important, mainly for the psychological benefits that it can generate, such as the feeling of being popular or happy. Lasch (1979), Giddens (1991), Holt (2002) also discuss market tyranny. Lasch (1979) argues that consumers have a false sense that they are free to choose when in fact they want and own identical products. In this assumedly apocalyptic view, the fantasy of variety and differentiation of products would be the fruit of propaganda resources. Giddens (1991) argues that the project of self is somehow translated as the possession of desired goods and the pursuit of artificially created lifestyles.

This debate about the market tyranny or freedom of the individual presupposes the consumer's lack of agency. Nevertheless, there is a third way, in which both the market and the individual are agents - that is, there is influence of the market on the consumer and, simultaneously, the interpretive and reflexive capacity of the consumer in relation to market stimuli. A line of consumer culture theory (eg. Ozanne \& Murray, 1995; Firat \& Venkatesh, 1995; Scott, 1994; Mick \& Buhl, 1992; Holt, 2002) indicates that the consumer has a creative ability to receive and reinterpret messages, and there is no definite relationship between the market action and the individual's reaction. Consumers are, under this view, "more interpretive agents than naive and passive" (Arnould \& Thompson, 2005, p. 875). This line of thinking moves towards the idea of emancipation of the individual and, as a result, to the concept of consumer resistance. Holt (2002), Ozanne and Murray (1995); Firat and Venkatesh (1995) mention a few instances of consumer resistance that include: (i) the emergence of the empowered consumer, who challenges the market; (ii) micro-market practices that fragment the market and make it less homogeneous; (iii) the possibility of rational choices derived from consumer education; and (iv) the confrontation with the market that happens, among other forms, when the products become symbols antagonistic to those aimed by their producers.

\section{Body and consumption}

The importance of appearance is described by Lasch (1979) as one of the undesirable effects of an excessively commercialized society, and such is true of consumer cultures. Being plain, unbecoming or repugnant is stigmatizing (Goffman, 2009). There is, however, the possibility of mitigating the condition of being "plain" by the individuals' ability to influence their body, either through disciplinary practices such as strict diets, through changing the way they dress, or through alternative ways of describing themselves. Cultural texts produced by fashion and cosmetics marketing agents, for example, may be useful for individuals to talk about themselves in order to reconstruct themselves narratively. It is possible that products made to distinguish consumers may be redescribed so as to reorder the dispossessed self of individuals whose appearance offends the aesthetic norm.

Thompson and Hirschman (1995) mention obesity and being overweight as physical conditions that generate cultural stigma, as if they might indicate that such individuals do not make an effort or care enough to change their situation. However, those whose weight is over the norm tend to attribute the "problem" to genetic issues, and not to a lack of discipline or effort. In this context, it is interesting to note the idea that this is a situation that always involves "accusation or justification" (Thompson \& Hirschman, 1995, p. 147). According to Fikkan and Rothblum (2005) there is, for example, a large bias in the labor market regarding obesity, especially in relation to obese women who, among other judgments, are seen as unkempt, with less self-control and discipline than "normal" women, and that they have difficulty establishing relationships with others. By contrast, the idea that beauty has a positive influence on individuals in the workplace is a conclusion by Harmersch and Biddle (1994, p. 1174), who state that being attractive can have a favorable influence on worker income: "Plain people earn less than average-looking people, who earn less than the good-looking." 
The standardization of the body, among other aspects, is reflected in everyday life through a mimicry incited by the media, which influences the construction and affirmation of individual identities by offering role models to follow. Such bodies refer to "those who are successful, who make smart decisions, who enjoy the taste of adventure and rare pleasures," say Rocha and Rodrigues (2012, p. 35).

Thompson and Hirschman (1995, p. 147) emphasize that such a pattern of normality disseminated by the mass media "is far from any sense of the average body" and carries the risk of creating problems with important personal consequences for those who deviate from the standards idealized by the norm. Also, in these authors' opinion, the cultural ideology spread by the media, by everyday beliefs, and by interpersonal relationships, impacts the way individuals interpret the symbolic meanings of the body and the way they care for their look.

Thus, if we consider that an individual's taste is domesticated by an aesthetic normalization, we will have the market as the actant imposing the norm - that would have the force to define the limits to what it means to be "normal" not only with respect to the appearance but also the (all) other spheres of an individual's life. In Bordo's words (2003, p. 11), bodies are strategically arranged

"... in ads and videos, in fashion that disseminates powerful lessons in how to view (and evaluate) bodies, also offering a fantasy of self-control, acceptance.... They tell young women not only how to be beautiful, but how to become what the dominant culture admires ...." (Bordo, 2003, p. 11).

In the author's view, this pressure creates insecurity about the body and learning to deal with it is part of an existential challenge, because surrendering to the model can mean a "fantasy of unlimited self-realization."

In a reference to Foucault (1996), we can consider that the market has the power to watch over the individuals and to punish them if they break the rule - by establishing a penalty that usually comes in the form of social prejudice and segregation. In the same way, we seem to make sense of the idea that the body shaped according to aesthetic standards can be compared to what Foucault calls a docile body, subject to the controlling power and discipline, in this case, of the appearance of individuals. Based on the other's gaze, which approves or disapproves of their appearance, people feel more or less in accordance with the norm, seeking to maintain their body in line with expected parameters (Foucault, 1996).

For Novaes (2006), a market logic was established in which there is no space for the singular, and all individuals should wish the same, as a characteristic of a global village. "The postmodern world has created a body type, and all the rest, to be accepted, must fit into the model. Slim - in short", say Del Priori and Armantino (2011, p. 9). Grogan (2008) confirms this pattern by pointing out that Western society encourages women to be thin and slender and, men, lean and (slightly) muscular - with the argument used by the diet industry that a lean body is healthier than an overweight one.

In this context, Eco (2004, p. 428) maintains that the media do not present a unique ideal of beauty, and there is an "unstoppable polytheism of beauty" in mass consumption. Costa (2004, p. 19), in line with Eco, refers to a variety of body shapes and functions, indicating that there are "different bodies for different kinds of happiness". It is, however, worth mentioning Rocha and Rodrigues (2012), who claim that the idea, in the industrial society, that each person has their own original and individual body, is paradoxical because, in fact, the individual is impotent. Defined as a "consumer body", this body would be a reflection of a society which, while indicating freedom, requires that some choice be made and where originality would have become commonplace.

"Irony: the moment I narcissistically contemplate and worship my 'own' individuality, the moment I promote it, by investing in it and becoming the entrepreneur of myself, I discover that this is the way of being that is the most averagely similar to everyone else" (Rocha \& Rodrigues, 2012, p. 36). 
The study conducted by Bell and Dittmar (2011) provides an interesting insight on body dissatisfaction and identification with body ideals present in media. They conclude that exposure to thin body ideals damages adolescent girls' satisfaction with their bodies irrespective of media type or exposure context, producing anxiety.

In this sense, it seems important to mention individuals who are (or seem to be) resistant to the aesthetic norm and react in a way so as to try) ignore or confront common sense - or simply do not consider the standards and go on with life. In any case, this tends to be seen as bizarre by others, as if it were exoticism or madness that escape from the norms of beauty (Kozinets, 2002; Arnould, 2007). Because they do not meet the standards and (apparently) manage their identity differently, they are defined as "exotic", "sloppy", and the worst of the insults: "ugly!"

More recent works in the consumer culture area have a critical view on the subject. Gopaldas and Seibert (2018) investigated deviations from the aesthetic norm intersectionally, stating that marketing images can be seen as "mirrors of intersectionality" in which all categorical forms of marginalization - namely "ableism, ageism, colorism, fatism, heterosexism, racism and sexism" (p. 20) are reflected. This way, it is difficult to understand "uglyism" per se, as it socially interacts with many other forms of deviation from normality. Scaraboto and Fischer (2013), using institutional logic to investigate how plus-sized bloggers - fatshionistas - contribute to market changes, concluded that plus-sized consumers, lacking cognitive-cultural legitimacy, are described as stigmatized seekers while looking for a better service from mainstream marketers, or resistant rebels when seeking for changes in the market logic. Such resistance movement is partially confirmed by Zanette and Brito (2018). In a study based on Foucault's idea of governability focusing plus-size female consumers, they propose the concept of complicit resistance: consumers strive to build their identity narratives recognizing an "inappropriate" fat body while surrendering to a lean body "when it reaches a threshold" (Zanette \& Brito, 2018, p.16).

\section{Ontological Security}

We live in a time in which there are many systems of cultural representation and, in this scenario, individuals play many roles and have many options available to establish their personal identity (Bauman, 2005). Goffman (2009, p. 43) uses the metaphor of theatrical performance to show that, in different social situations, individuals ("actors") play different roles, depending on the profile of the "audience" and its expectations of them. Giddens (1991, p. 190) confirms this proposition, indicating that an individual "sensitively adjusts the 'presentation of self' in relation to whatever is demanded of a particular situation."

Giddens (1991, p. 12) specifically addresses the concept of self-identity - a reflexive project routinely upheld by individuals, that is, a way to sustain "coherent, yet continuously revised, biographical narratives". Reflexivity occurs when subjects try to be aware of themselves, their thoughts and their feelings, that is, their "self". It is self-observation, self-therapy, a narrative capable of generating enough self-knowledge that may lead to changes. It leads individuals to plan for the future in keeping with their innermost desires and to design their "ideal self," that is, what they would like to be. "The self is seen as a reflexive project for which the individual is responsible... We are, not what we are, but what we make of ourselves", asserts Giddens (1991, p. 74).

The concept of ontological security, presented by Giddens (1984) can be loosely defined as the ability to live life positively, without existential issues causing disruption. When individuals are secure regarding the continuity of their biography, they are also secure regarding other existential issues, such as their self-identity, and this comprises their ontological security. More than being aware of one's self-identity, ontological awareness refers to "being", to living everyday life according to the reflexive project of the self; to having essential parameters for planning for the future; to giving meaning to life. If their ontological security is compromised, individuals can be struck by the "slightest glance of one person towards another, inflexion of the voice, changing facial expression or gestures of the body" (Giddens, 1991, p. 52). For them, life is a broken narrative 
and, therefore, their biography is fractured. Worry, fear and anxiety related to the outside world are so bad that these individuals are unable to act. They question themselves so much and feel so threatened that they lack all spontaneity in life. For Goffman (2009, p. 239), when individuals look at the world around them and believe they can follow their routine unhindered, they feel safe to continue, "with only peripheral attention given to checking on the stability of the environment".

Since the body is one of the elements by which individuals maintain their biography, it is part of the discussion of ontological security. For example, existential anxieties may reflect an unwanted separation between the body and the self, and this interferes with one's self-identity (Goffman, 2009). The body is not an element outside the self; it is mobilized by reflexive processes and connected to abstract systems, that is, systems that represent a tangle of relationships on which individuals rely and over which they have little influential power, such as technology, for example. "To learn to become a competent agent - able to join with others on an equal basis in the production and reproduction of social relations - is to be able to exert a continuous, and successful, monitoring of face and body", asserts Giddens (1991, p. 56).

Ontological security has close correlation with security in the environments and relationships that are part of the routine, with the peace of mind that there will be no ruptures. Confidence takes the individual away from negative sensations and ideas, such as anxiety and risk. Such unfavorable sensations derive from the complexity of contemporary life, which presents us with innumerable options for every choice we must make. If, on the one hand, they indicate a certain freedom of choice, on the other hand, they represent the risk of making a wrong decision due to insecurity or lack of parameters. (Giddens, 1984, 1991).

Ontological security does not mean pride or selfishness, the characteristics of a self-directed individual who underestimates social relations. Nor can it be confused with narcissism - a concept that expresses an exacerbated preoccupation with the self, in an incessant search for satisfaction that hinders its connection with the outside world (Castro, 2003). The narcissistic subject focuses on the search for self-identity and self-realization, with a sense of grandeur that is confused with boredom, with a sense of emptiness. He does not like to compete because he fears being defeated, and he makes sure that the rules are fulfilled, as long as they do not apply to him. To feel important and capable, he is always waiting for the other's admiration (Lasch, 1979; Giddens, 1991). He is an anxious subject who wants not only to "impose his certainties but to discover meaning for life". Although apparently secure, "he doubts even the reality of his own existence" (Lasch, 1979, p. xvi).

\section{Practical Research procedures}

This work is based on an interpretivist perspective, which delves into the subjectivity of social actors to understand their motivations, beliefs and desires, with a view to understanding the social world based on their awareness of it. Data production occurred from October 2012 to July 2013 in Rio de Janeiro. As a coastal city with a hot climate, the exposition of bodies and the release of fads related to physical appearance are recurrent. According to Goldenberg (2011, p. 8), Rio de Janeiro "is an ideal place for studying body worship," where preoccupation with one's appearance, is one way or another, frequent among people irrespective of age groups or social classes.

As Belk, Fischer and Kozinets (2013, p. 32) assert, considering the fact that "a good depth interview begins before you enter the field", the preparation stage was conducted with great care. In the recruitment stage, informants were guaranteed anonymity regarding the information collected for the study, and were warned that it would be necessary to reserve a part of the day for the interview because it would not be just a quick chat. To ensure privacy, the interviews took place at the respondents' residence or in rooms at their study or workplace. 
The recruitment of respondents was made initially through accessibility (Gil, 2010; Godoi \& Mattos, 2010), in the researchers' network of relationships. In this respect, as Thompson and Hirschman (1995, p. 140) mention about their informants, the participants were all known to the interviewer, "which greatly facilitates the natural flow of conversation". In order to carry out the interviews, contacts were made personally or via electronic mail. The objective of the research was described as an investigation about factors related to body and physical appearance.

Before each interview, informants signed an ethical protocol authorizing the use of their testimony. Twenty-one interviews were conducted. There were no restrictions in terms of age and economic or social class. By the end of the data production stage, men and women ranging from 18 to 50 years old from economic classes A, B and C (according to the Brazil Criterion for Economic Classification, Abep [Brazilian Association of Research Companies], 2012) had been interviewed. Both single and married individuals, with or without children, all residents of Rio de Janeiro were interviewed. Professional activities varied, including psychology, engineering, economy, public servants and entrepreneurs. Interviews were halted as soon as saturation of collected data was reached (Bauer \& Aarts, 2002).

Interviews lasted an average of 1 hour and 42 minutes, totaling 30 hours and 41 minutes of audio recording. They were conducted using a script consisting of a list of topics prepared in such a way as to give the interviewer flexibility in the ordering of the issues, as well as the inclusion or exclusion of a particular topic during the conversation (Godoi \& Mattos, 2010; Gaskell, 2003). In the first part of the interviews, subjects were encouraged to bring information about their family and work life and, in the sequence, concerns about body and the care of the body were explored. In constructing the script, we sought to start the interview with more general subjects and then address specific topics, using a funnel-like design, as recommended by Belk et al. (2013) and McCracken (1988). The script was tested in a pilot interview and, after evaluation, adjustments were made. The interviews began with a grand tour type question (McCracken, 1988; Belk et al., 2013), and were conducted as an "apparently natural and almost casual conversation" (Gaskell, 2003, p.40), seeking to explore selected issues without the interviewees being interrupted, and revisiting some comments for their better understanding. All interviews were audio-recorded and transcribed in full, verbatim.

The data were analyzed discursively. Unlike content analysis, the objective of discourse analysis is not to categorize speech, or to find and describe irregularities; rather, it is meant to identify and reflect on "dispersion, differences and discontinuity of planes whence the subject is speaking" (Godoi, 2010, p. 387). Vergara (2008, p. 27), however, explains that discourse analysis does not rule out content, but goes further by examining functions, meanings and "how content is used to achieve certain effects".

In this study, the French line of discourse analysis was adopted, particularly from the point of view of Pêcheux (1993) and authors who follow his theory, such as Orlandi (2009), Maingueneau (2013) and Sarfati (2010). We adopted such approach to capture elements that would not be evident in a simple content analysis, since most of them are not evident to informants' conscience. After all, discourse analysis assumes that language is not naïve or transparent, and is, therefore, able to reveal "ambiguities of social constructions" (Alvesson \& Karreman, 2000, p. 1127).

Three elements proper for discourse analysis will be mentioned in the data analysis that follows. These elements are polyphony, intertextuality and interdiscursivity. Polyphony, according to Koch (2004, p. 140), indicates a "chorus of voices that usually manifests in discourse, aiming to be the thought of the other that constitutes our own". Maingueneau (2013, p. 163) also talks about other voices in addressing the idea of polyphony: "When interlocutors speak, they are not content with expressing their own opinions; on the contrary, they express many other voices, more or less clearly identified, in relation to which he is situated." According to Fiorin (1994), textual and discursive polyphony, respectively, correspond to the concepts of intertextuality and interdiscursivity. In intertextuality, one or more texts are incorporated into another, maintaining or changing their meaning and generating "an intense circulation from one area of knowledge to another .... with highly diverse exchanges taking place according to the discourses and circumstances under consideration" (Brandão, 
2006, p. 95). This happens, for example, when expressions (discursive objects) from one area of activity or knowledge are used in another area of activity or knowledge. If, however, not only the words, but the way of speaking is transferred from one area of activity or knowledge to another, there is interdiscursivity. These elements are essential for identifying discourses coming from the marketing world into the lives of individuals and their ontologically secure identity constitution.

\section{The data}

Reports by the informants revealed instances of discomfort or conflict in their relationships with their own bodies. In their statements, it was sometimes possible to clearly identify aspects such as low self-confidence, self-esteem or willpower. This was revealed in a somewhat incoherent narrative about themselves, which was interpreted as "gaps" in their ontological security. Ontological security is more easily identified through its absence. This way, special attention was given during the interviews and analysis to declarations of discomfort, inadequacy, or extreme self-conscience. At times, some informants seemed to be confident about themselves and were clear and secure about their social identity, but at other times they revealed a certain vulnerability, indicating concern about what others thought about their appearance or certain habits, not exactly by personal decision, but as something related to the expectations of those who will henceforth be called "others," that is, the look and opinion of other people in particular, or of society as a whole. Some of these "gaps" in ontological security are discussed below. The names of the informants have been changed for their protection.

Data will be described and organized in four large categories that emerged on data analysis: "struggles with self-demands", "extreme disciplinary routines (anorexia)", "self-confidence building", and "the parts and the whole". These categories describe limit cases where the struggle to build a coherent self - searching for ontological security - are identified.

Struggling with self-demands

One can see an elevated amount of self-demand regarding appearance, noting that even those whose body seems to correspond to what is defined by the aesthetic norm express dissatisfaction and the desire to improve one thing or another about their looks. It was common to hear from the informants expressions such as "nothing is so good that it cannot be made better," which generates anxiety and an ongoing sense of frustration - ratifying what authors such as Castro (2004) and Bell and Dittmar (2011) say. Much of this demand lies in issues about weight. Glória, for example, discursively transfers her discomfort with her body to a more generic context, saying that all women feel as she does.

When I weighed, like, 53 kilos, the least I ever weighed, I was really skinny, too skinny, actually. Even then I wanted to lose about 3 more kilos. Women are like that. They're never satisfied with their body and I'm totally like that (Glória, 19 years old).

Existing aesthetic standards entail products and services that nourish individuals and are nourished by them at the same time. For example, some of these services, such as fitness centers and personal trainers, produce important discursive objects in the informants' narratives. Another powerful source of influence is the mass media, and Glória's statement is in line with Bell and Dittmar's (2011) conclusions about body dissatisfaction among adolescent girls. Gloria's generalization seems like a rational attempt to cope with ontological insecurity related to body shape. These discursive objects often emerge in what the interviewees say during the interviews, revealing important interdiscursivity that characterizes the presence of discourses emanating 
from marketing activities (as the ones Bell and Dittmar (2011) investigated) in the constitution of the narrative identities. The following from Amanda's interview is a good example:

I think I could do better. I mean I'm thin right now, but being thin isn't my goal. My goal is to be thin and very strong... Have muscle mass. My legs aren't toned. They're just normal. No cellulite, nothing. Just normal legs. My goal is to get them toned (Amanda, 34).

Bearing in mind the presence and influence of marketing stimuli on consumers (Bell \& Dittmar, 2011; Gopaldas \& Seibert, 2018; Zanette \& Brito, 2018), references to muscle mass and toning reveal the presence of discursive elements from bodybuilding, for example, which constitutes an intertextuality that reveals this informant's wishes about her appearance. As a whole, her testimony is a reminder, for example, of the discourse of ad campaigns to promote beauty products and services that use testimonials to generate identification with the target audience. It is as if, at the end of her statement, she was alluding to a brand that promises to transform "normal legs" into "toned legs". Discursive objects from physical education (PE) are frequently present, indicating intents that go beyond aesthetical beauty, reaching body transformation. The testimony of Paul, 41, is striking in this regard. The transference of knowledge and discursive objects amongst activities is intense in his interview. He is a man who is uncomfortable with being 41 years old because his age interferes with the strict disciplinary routine he has followed since adolescence.

But that's just the way it is, you know? I don't need professionals (e.g. nutritionists, personal trainers) any more for any of those things, because I learned from them over the course of 20 years... I've watched how the profession has developed. Lifting weights meant being concerned basically with my muscles. But nowadays it's more about my joints... And I've also learned a bit from professionals about my joints... I've incorporated that into what I know. I've also learned about nutrition from professionals, not so much from direct contact with them, but from reading. I've always read a lot about nutrition. When I go to the supermarket, I always check the amount of protein and carbs... (Paul, 41).

This self-demand regarding the body, which causes anxiety and reveals weak ontological security, can also be seen in the testimony of Sara, 23. In the following excerpt, when talking about her body, she repeats the word "skinny" several times, as if talking to - and almost blaming - herself for being that way.

I know I'm skinny. I look in the mirror and say: Skinny!... The second you decide to put on a bit more, you already feel bad. ...Sometimes I look and say to myself: 'Uh oh, l've put on some weight,' and then I say, 'Oh, get off it!... I'm skinny, skinny, skinny.' (Sara, 23).

Paul and Sara, albeit indicating signs of ontological insecurity, differ at how they cope with their dissatisfaction. While Paul dedicates himself to strict disciplinary body routines, assuming a certain level of agency towards his body, Sara just complains, blatantly showing a conflict with her body. On the one hand, her job - dancing - requires her to be very thin. On the other, there is the market normative aesthetic model, which she would also like to comply with, but which prescribes another kind of thinness - it can be called "thin with curves". Accordingly, when she says, for example, "I've never felt sexy", she produces a narrative full of apparent contradictions.

I've never felt sexy.... I'm really pleased with my boobs. I wouldn't want bigger boobs. And then there's, 'Ah, you're a fake skinny. You're skinny, all right, but you've got boobs and a butt. Everything's there. If you worked out, you'd be fantastic.' ...I don't know if I'm really a fake skinny. I don't think people ever have a perfect opinion of their own body. People don't see what they really are (Sara, 23). 
Such contradictions confirm not only the never-ending romantic desire for new objects and experiences described by Campbell (2001), but also Dittmar's (2011) beliefs about the role of mass media in producing such objects of desire. It is also interesting to note her reference to the term "fake skinny": an example of intertextuality, it is a fashion market expression used to describe a certain thin biotype - namely, a thin body, but one that has curves. Thus, as shown by Sara's own testimony, being called a "fake skinny" is a compliment.

The incorporation of discursive objects from the health and physical education fields is blatant here, particularly in Paul's speech. Not only market agents - fashion industry, cosmetics, body shaping - are present, but also the interplay between the ideal body produced in advertising and cultural industry products present in expert discourses, and the demands the informants are subjected to when caring about their bodies.

Extreme disciplinary routines: Anorexia

Henry, 18, is an informant whose ontological security gaps are revealed in the pronoun reversal he uses in his testimony, talking about himself in the third person. When refers to himself as an "other", Henry reminds us of the conflict between a person and "the mirror" depicted on the "You vs. The Mirror" Shiseido campaign": the "other" reflected in the mirror is an adversary. When talking about his body, he reveals the suffering caused by his anorexia. His distorted self-image has led him to have attitudes that are proper to those who have this disorder, such as overdoing physical exercises, throwing food out behind his parents' backs, and being obsessed with counting calories. Self-help books are present in how he narrates his practices.

As much as people talk, man ... [...] l'd love to say I'm good-looking. I've tried saying it in front of the mirror. I've read self-help books ... I've stood in front of the mirror repeating the mantra [I am handsome]... (Henry, 18)

From what the informant says, anorexia - at least in his case - seems to have to do with a crisis in several identity spheres generated by family conflicts. For Giddens (1991), rather than being a pathological reaction to growth and maturity, or an out-of-control search for an aesthetic ideal of thinness, anorexia is an extreme example of reflexivity, in which the individual actively acts on his or her body. In line with Gopaldas and Seibert (2018), intersectionality takes place here: it is sometimes difficult to understand "uglyism" on itself. Informants' reflexivity must be analyzed as a complex confluence of problems related to age, gender, social class, and practices (habitus).

Reflexivity is also apparent in the testimony of Beatriz, 29, an informant who suffered from anorexia and bulimia, and now claims to have the diseases under control, although she knows she cannot be considered permanently cured. She realizes that anorexia influenced her relationship with her body, but rationally argues that practicing Pilates was also decisive:

I see myself... I look at my body ... I had anorexia and everything else. I had this aesthetic concern. It was not actually beauty per se, but thinness. So, I notice every centimeter. I got used to seeing my body with every centimeter that it changes.

... So, l've gone from having a pathology to having body consciousness, to being aware of my body per se. I also do Pilates, and Pilates helps me with it a lot, because I'm doing an exercise where I have to be aware of the movement I'm doing. And to be aware of the movement I'm doing, which strengthens my muscles, improves my balance, helps me breathe, and calms me down, I have to know where my legs and arms are, their size, strength and so on. That's the body consciousness I have today: I know my body's limits (Beatriz, 29).

1. Available at: https://editorial.femaledaily.com/blog/2016/08/23/ayo-ikut-you-vs-the-mirror-beauty-workshop-bersama-shiseido/ 
There is intertextuality when she mentions she is aware of "every centimeter" of her body, "body consciousness," and that practicing Pilates makes her "aware of the movement," "helps [her] breathe" and "improves [her] balance". These statements refer to marketing messages, in which the focus is on the ideas of self-knowledge and well-being. The seemingly increasing offer of Pilates sessions in studios spread over the richest areas of the city and the resulting popularization of narratives related to its practice are important to the discursive construction of a reflexive monitoring capacity to cope with anxieties that could otherwise harm a person.

\section{Trying to build self-confidence}

Mariana, 46, acknowledges being overweight, taking into account the aesthetic norm, but during the interview she repeatedly stated that she "feels good" about herself, and that the fact that she is "plump" does not keep her from seeing herself as an attractive woman. In addition, the fact that she has just got married for the second time is prevalent in her interview, narratively highlighting the appeal of her body, capable of attracting the desire of another. Mariana describes herself saying, "I'm short, plump, brunette, friendly, and I have a beautiful smile," and she affirms herself with expressions such as "I feel great," and "I really like myself," utterances that can be seen as rejecting an interpretation of herself that could cause anguish. There are indications that her body is an issue that does upset her, especially because there are contradictions when she says, for example, "I wouldn't change one thing about myself" and then right afterwards, "I know I need to lose some weight." Instances of interdiscursivity appear in Mariana's testimony when she discusses beauty industry goods and services. For example, she describes her hair in a way that is very similar to the text from an ad:

I think the radiance from the dye (hair coloring product) opens my face more, and my hair is always shiny. It's wonderful when you're walking on the street and people ask, 'What do you do? What hair dye do you use? Who's your hairdresser?' (Mariana, 46)

Another informant who, in a first reading, demonstrates broad acceptance of herself and her body is Barbara, 34. She used to be obese, so she underwent bariatric surgery. Today she talks about herself with pride and signs of confidence. Her manner of talking about her amorous conquests shows a very interesting interdiscursive event:

Oh, I get excited, all right, but I also get unexcited just as easily... my line of flings doesn't walk; it runs like a Ferrari. It's sort of like that... and I give myself totally. I get involved, but the second I feel uncomfortable, I hit delete. (Barbara, 34)

Although she describes herself as a "very lonely" girl who "couldn't find herself", and who had a very bad adolescence because she was fat, bariatric surgery and weight loss enabled her to describe herself as someone who is in love with life to the point of describing her love life using powerful discursive objects such as "my line of flings doesn't walk; it runs like a Ferrari", or "the second I feel uncomfortable, I hit delete". These are interdiscursivities evoking a marketing object related to the world of men (Ferrari) or technology (the word "delete").

Another interesting fact about Barbara, but which also shows up in other interviews, is the satisfaction afforded by openness to the marketing world when one loses weight. Not only does one meet the aesthetic norm, but one also wins one's passport to the market. 
Shopping and fashion; for me it's fun... I never used to actually buy anything - I couldn't, because nothing fit, and because I didn't have any money. Now things do fit and I do have money... (Barbara, 34).

Barbara is definitely not aligned with the description given by Scaraboto and Fischer (2013) of what they call "fatshionistas", girls that engage in action on social media to come to terms with their physical dissatisfaction, since her approach is much more directed towards herself than to the community of overweight women, a description that does not describe her socially anymore as she recurred not only to narratives, but also to surgical intervention in her body to gain a bit of confidence and social approval. After all, she acts in order to conform with what is seen as an ideal body. As a matter of fact, not only Barbara's but also Paul's stories confirm what Zanette and Brito (2018) called complicit resistance. In terms of someone else's approval, the testimony of Paul, 42, stands out. He says that everything he does in life is aimed at receiving compliments for it, i.e. being acknowledged by others.

I would say that the purpose for everything I do in life is to receive recognition in the form of praise. That goes for both my professional life and my personal life. Sun-tanning, working out and dancing are things that help me get that recognition and praise... (Paul, 42).

His heightened self-awareness is confirmed by the several daily rituals he follows for taking care of his body, and by the ingrained habit of checking his visual appeal. He personally monitors his measures and speaks of them precisely, spontaneously including in his text numbers that indicate the size of his body and its changes, such as: "My belly got bigger, but my arms also went from 30 to 35". The mirror is, in this sense, a valuable object for this interviewee, who, instead of looking at his reflection to make a general assessment, tends to look at it very critically and in detail. He says he is pleased with what he sees, particularly with the definition of his muscles and small amount of body fat. He believes he has "a body that gets the girls". His self-esteem is conditioned by how others see him.

Partitions of the body: The Parts and the whole

Belk (1988) proposed the concept of the extended self to explain that, just as certain objects are central for maintaining a sense of self (recognized here as a coherent narrative identity), there are also parts of the body with which one acknowledges oneself more strongly. Belk (1988) explains that the extended self is a concept that contributes to understanding human behavior and, within it, consumer behavior. In line with this argument, one can see that, for some of the interviewees, there are parts of the body that seem to be the targets of more attention regarding which ones cause more pride or frustration. It is as if they were areas on a map, which, for some reason, need to be marked, about which there is something special to say and analyze because they help to better understand the whole and its essence. These are somehow related to one's identity, but they may also be related to one's ontological (in)security because they can interfere with matters such as self-esteem, control and autonomy.

I don't like my arms... I think they're fat. And I also have allergies. My arms have a bunch of red splotches and stuff. I really don't like 'em! (Glória, 19).

In describing certain physical characteristics, some informants compared themselves - or parts of their bodies - with mass media characters. This interdiscursive process indicates that the description of selected parts of their body is mediated by cultural products such as cartoon characters, for instance. 
When I'm bloated, looking like Garfield [comic strip character], I have to take my diuretics. (Henrique, 18).

There is interdiscursivity when they talk about parts of their body, and one can identify the marketing discourse in several of the testimonies and in two other situations. First, when they use expressions with an emotional connotation to refer to the parts of the body they value, as if personifying them. Moreover, they resort to adjectives that are proper to marketing to indicate desired attributes.

My abs have to be like a tank: defined; ripped. (Vera, 32).

My boobs make me secure as a woman. I've got boobs! ...l look at them and say: 'You've got all that... You're awesome."' (Raquel, 26).

A second interdiscursivity happened when informants speak about parts of their body as if, although members of the whole, they were independent of it. Furthermore, they can be seen as parts to be manipulated, relegating the whole to the background. Or they can be seen as products that can be improved, exchanged or renewed. They are parts of the body that are often viewed with pride, perhaps sometimes incompatible with the narratives that describe the body as a whole.

Once I went to Fashion Rio with a friend of mine. I was in one of the lounges there and a guy handed me one of his cards... He worked for a nail polish brand... He said, 'I think you've got beautiful hands. Here's my card. Call me. Look me up so we can do something with your hand' (Sara, 23).

I'm OK from my quads up to my pecs ... I like that, except for my arms. I like my abs, my boobs, my back.... But my legs and arms... if I could, l'd put on $2 \mathrm{~kg}$ on each [leg] and $1 \mathrm{~kg}$ on each [arm] ... (Sara, 23).

The plain, uninteresting, or challenging appearance that can be described as stigmatizing (Goffman, 2009) is apparently mitigated here by its fragmentation. It is as if a high value attributed to one fragment of the body could be used as compensation to neutralize a negative bias produced by a weak and difficult overall appearance described by Harmersch and Biddle (1994), and Fikkan and Rothblum (2005).

\section{Conclusions}

Consistent with authors such as Giddens (1991), Goffman (2009), and Schouten (1991), it was clearly observed that the body is something important in individuals' idea of themselves, and it is part of their identity construction. It is evident that, when they talk about their appearance, they are not merely referring to physical characteristics. Instead, they include references about their life story, their relationships with others, their desires and their anxieties. In this sense, the body is an element that, in some way, is part of their "self", not only its tangible reflection. Thus, understanding consumer practices related to the body as a reaction of compliance or non-compliance with the aesthetic norm brings an incipient insight to the issue. As indicated throughout this study, such practices are related, for example, to the identity and ontological security of each one.

The concepts of identity (Hall, 2011; Silva, 2005; Taylor, 1992; Giddens, 1984), ontological security (Giddens, 1984) and aesthetic normativity (Thompson \& Hirschman, 1995) substantiate this study. Besides confirming the presence of marketing discourse in narratives and practices related to the body, the results show that congruencies and incongruences in narrative identities may be related to discourses emanating from marketing, which provide and/or reproduce arguments for individuals to evaluate themselves and compare themselves to others. 
The testimonies indicate that, with greater or lesser emphasis, the interviewees have a conflictual relationship with their body, which confirms the theoretical argument of Grogan (2008) regarding men and women's dissatisfaction with their appearance. The way they see their bodies and how they might project an ideal body is reflected in their narrative identity, and is therefore closely tied to their self-perception as individuals and to the way they want to be seen by others - something that, in some way and to some degree, can cause anxiety. In this context, one can say that the evaluation of one's body and management of one's appearance tend to experience major influences from marketing messages, as indicated by authors such as Rocha and Rodrigues (2012), Novaes (2006), Castro (2003), Thompson and Hirschman (1995), and Bordo (1989, 2003).

Discourses coming from service providers such as dietitians or personal trainers permeate the informants' narratives. Sometimes these discourses appear as powerful aids in maintaining a coherent narrative between their self-perception and the 'regard' of others. At other times, they appear to function as destabilizers of a narrative identity that otherwise could find stability. This aspect is important to understand the relationship between identity, body and ontological security. Grogan (2008) has pointed out that there always is some dissatisfaction with some physical trait. Such dissatisfaction interacts positively or negatively with gaps in one's ontological security, which leads to the anguish of not living up to (or not fully living up to) the standard. Individuals' discontent with their appearance tends to be generated by the models that marketing offers. This conclusion confirms the initial premise of this work, which indicated that individuals see their bodies through the lenses of marketing. Marketing not only promotes perfect bodies and disseminates messages that stimulate investment in the body's appearance as a whole and in its separate parts - such as hands, feet, hair, legs and many other pieces of the whole -, forming a large set of actors clamoring for attention and investment. Markets also offer discursive objects which individuals/ consumers use to mitigate their self-image and self-identity problems.

The way individuals deal with messages coming from marketing actants - often normative - offers clues about their ontological security. Ontologically secure individuals are not necessarily those who disregard marketing and whose consumption practices regarding their body avoids the aesthetic norm. They can indeed agree with what the market expects of them as consumers. What sets them apart from those with fragile ontological security is their motivation to adhere to a certain stimulus, the way they handle these consumer choices.

Individuals who have gaps in their ontological security are more anxious regarding marketing messages. There is some degree of suffering when they do not live up to the aesthetic norm, and the appearance of their body takes up an overwhelmingly large space in their narratives. It is as if, more than simply wishing to understand the norm, they have to live up to it; that is, as if it were not an option, but a necessity they have not thought about. In line with Zanette and Brito (2018), they resist the market and coalesce to its demands at the same time, in what they call complicit resistance. There is self-demand and frustration because they believe there is always something urgent regarding improving their body, which confirms what authors such as Thompson and Hirschman (1995) and Grogan (2008) say. Some tend to deny this anxiety, using marketing discursive objects to justify their consumer practices related to the body. Thinking about the efforts to keep some ontological security, it seems to be a sort of resistance that saves the person's identity by reinterpreting or redescribing marketing stimuli.

These results represent a contribution to studies and marketing practices to the extent that the market is a central element in the analysis of the relationship between individuals, their body and their ontological security. By analyzing impacts of the aesthetic norm on individuals, by understanding how ontological security can generate differences among consumers, as well as by ascertaining consumer practices and discourses concerning the body, among other issues addressed here, this work contributes to the understanding of consumer phenomena in society. These results are valuable to marketers as long as they understand the social and ethical limits of their activities. One way of creating possibilities for consumers with spoiled identities (Goffman, 2009) is through more open messages, which could be readily reinterpreted by consumers. In a way, advertising 
humor or cynicism might open important possibilities to reinterpretation, and as such, it opens interesting questions for future investigation related to ontological security. Such research could be invaluable not only to public policies related to communication, but also to advertising self-regulation.

\section{References}

Alvesson, M., \& Karreman, D. (2000). Varieties of discourse: On the study of organizations through discourse analysis. Human Relations, 53(9), 1125-1149.

Arnould, E. J. (2007). Should consumer citizens escape the market? The Annals of the American Academy of Political and Social Science, 611(1), 96-111.

Arnould, E. J., \& Thompson, C. J. (2005). Consumer culture theory (CCT): Twenty years of research. Journal of Consumer Research, 31(4), 868-882.

Barbosa, L., \& Campbell, C. (2007). Cultura, consumo e identidade. Rio de Janeiro: Editora FGV.

Bauer, M. W., \& Aarts, B. (2002). A Construção do corpus: Um princípio para a coleta de dados qualitativos. In M. W. Bauer, \& G. Gaskell (Eds.), Pesquisa qualitativa com texto, imagem e som. Petrópolis: Vozes.

Bauman, Z. (2005). Identidade: Entrevista a Benedetto Vecchi. Rio de Janeiro: Zahar.

Belk, R., Fischer, E., \& Kozinets, R. V. (2013). Qualitative consumer and marketing research. London: Sage Publications.

Belk, R. W. (1988). Possessions and the extended self. Journal of Consumer Research, 14 (2), 139-168.

Bell, B. T., \& Dittmar, H. (2011). Does media type matter? The role of identification in adolescent girls' media consumption and the impact of different thin-ideal media on body image. Sex Roles, 65(7), 478.

Bordo, S. (1989). The body and the reproduction of femininity: A feminist appropriation of foucault. In A. M. Jaggar, \& S. R. Bordo (Eds.), Gender/body/knowledge: Feminist reconstructions of being and knowing. New Brunswick, N.J.: Rutgers University Press.

Bordo, S. (2003). No império das imagens: Prefácio para o décimo aniversário da edição de "Este peso insuportável". Labrys, estudos feministas, 4 (august/december).

Brandão, A. (2006). Entre a vida vivida e a vida contada: A história de vida como material primário de investigação sociológica. Configurações, 3, 83-106.

Campbell, C. (2001). A ética romântica e o espírito do consumismo moderno. Rio de Janeiro: Rocco.

Castro, A. L. (2003). Culto ao corpo e sociedade: Mídia, estilos de vida e cultura de consumo. São Paulo: Annablume.

Castro, A. L. (2004). Culto ao corpo: Identidades e estilos de vida. Paper presented at the Congresso Iuso-afro-brasileiro de ciências sociais, VIII, Coimbra, Portugal.

Costa, J. F. (2004). O vestígio e a aura: Corpo e consumismo na moral do espetáculo. Rio de Janeiro: Garamond.

Dittmar, H. (2011). Handbook of identity theory and research: Domains and categories. In S. J. Schwartz, K. Luyckx, \& V. L. Vignoles (Eds.), Handbook of identity theory and research (pp. 745-769). New York: Springer.

Del Priori, M., \& Amarantino, M. (2011). História do corpo no Brasil. São Paulo: Editora UNESP.

Eco, U. (2004). História da beleza. São Paulo: Record. 
Featherstone, M. (2000). Body modification. London: Sage Publications.

Fikkan, J., \& Rothblum, E. (2005). Weight bias in employment. In: K. D. Brownell, R. M. Puhl, M. B. Scwartz \& L. Rudd (Eds.), Weight bias: Nature, consequences, and remedies. New York: Guilford Press.

Fiorin, J. L. (1994). Polifonia textual e discursiva. In: D. P. Barros \& J. L. Fiorin (Eds.), Dialogismo, polifonia, intertextualidade: Em torno de Mikhail Bakhtin. São Paulo: EDUSP.

Firat, A. F., \& Venkatesh, A. (1995). Liberatory postmodernism and the reenchantment of consumption. The Journal of Consumer Research, 22(3), 239-267.

Foucault, M. (1996). Vigiar e punir: História da violência nas prisões. Rio de Janeiro: Vozes.

Gabriel, Y. (2015). Identity, choice and consumer freedom - the new opiates? A psychoanalytic interrogation. Marketing Theory, 15(1), 25-30.

Gaskell, G. (2003). Entrevistas individuais e grupais. In M. W. Bauer, \& G. Gaskell (Eds.), Pesquisa qualitativa com texto, imagem e som. Petrópolis: Vozes.

Giddens, A. (1984). The constitution of society: Outline of the Theory of Structuration. Cambridge: Polity Press.

Giddens, A. (1991). Modernity and self-Identity: Self and society in the late modern age. Cambridge: Polity Press.

Gil, A. C. (2010). Como elaborar projetos de pesquisa. São Paulo: Atlas.

Godoi, C. K. (2010). Perspectivas de análise do discurso nos estudos organizacionais. In: C. K. Godoi, A. B. Silva, \& R. Bandeira-de-Mello (Eds.), Pesquisa qualitativa em estudos organizacionais. São Paulo: Saraiva.

Godoi, C. K., \& Mattos, P. L. C. L. (2010). Entrevista qualitativa: Instrumento de pesquisa e evento dialógico. In: C. K. Godoi, A. B. Silva, \& R. Bandeira-de-Mello (Eds.), Pesquisa qualitativa em estudos organizacionais. São Paulo: Saraiva.

Goffman, E. (2009). Stigma: Notes on the management of spoiled identity. New York: Touchstone.

Goldenberg, M. (2011). Nu e vestido: 10 antropólogos revelam a cultura do corpo carioca. Rio de Janeiro: Record.

Gopaldas, A., \& Siebert, A. (2018). Women over 40, foreigners of color, and other missing persons in globalizing mediascapes: Understanding marketing images as mirrors of intersectionality. Consumption Markets \& Culture, 21(4), 323-346.

Grogan, S. (2008). Body Image: Understanding body dissatisfaction in men, women and children. New York: Routledge.

Hall, S. (2011). A identidade cultural na pós-modernidade. Rio de Janeiro: DP\&A.

Harmersch, D. S., \& Biddle, J. E. (1994). Beauty and the labor market. The American economic review, 84(5), 1174-1193.

Holt, D. B. (1997). Poststructuralist lifestyle analysis: Conceptualizing the social patterning of consumption in postmodernity. Journal of Consumer Research, 23(4), 326-350.

Holt, D. B. (2002). Why do brands cause trouble? A dialectical theory of consumer culture and branding. Journal of Consumer Research, 29(June).

Jenkins, R. (2008). Social identity. Oxon: Routledge.

Koch, I. G. V. (2004). Argumentação e linguagem. São Paulo: Cortez Editora. 
Kozinets, R. (2002). Can consumers escape the market? Emancipatory illuminations from burning man. Journal of Consumer Research, 29.

Lamont, M., \& Molnar, V. (2001). How blacks use consumption to shape their collective identity. Journal of Consumer Culture, 1(1).

Lasch, C. (1979). The culture of narcissism: American life in an age of diminishing expectations. New York: W. W. Norton.

Luedicke, M. K., Thompson, C. J., \& Giesler, M. (2010). Consumer identity work as moral protagonism: How myth and ideology animate a brand-mediated moral conflict. Journal of Consumer Research, 36(6), 1016-1032.

Lunt, P. (1995). Psychological approaches to consumption. In: D. Miller (Ed.), Acknowledging consumption: A review of new studies. New York: Routledge.

Maingueneau, D. (2013). Análise de textos de comunicação. São Paulo: Cortez Editora.

McCracken, G. (2010). Cultura e consumo: Novas abordagens ao caráter simbólico dos bens. Rio de Janeiro: Mauad.

Mick, D. G., \& Buhl, C. (1992). A meaning-base model of advertising experiences. Journal of Consumer Research, 19 (December), 317-338.

Novaes, J. (2006). O intolerável peso da feiúra. Rio de Janeiro: Editora PUC-Rio.

Orlandi, E. P. (2009). Análise de discurso: princípios \& procedimentos. Campinas: Pontes Editores.

Ostergaard, P., Fitchett, J. A., \& Jantzen, C. (1999). On appropriation and singuralisation: two consumption processes. In: E. J. Arnould, \& L. M. Scott (Eds.), Advances in consumer research. Provo, UT: Association for Consumer Research.

Ozanne, J. L., \& Murray, J. B. (1995). Uniting critical theory and public policy to create the reflexively defiant consumer. American Behavioral Scientist, 38(4), 516.

Pêcheux, M. (1993). Análise automática do discurso. In F. Gadet, T. Hak, \& B. S. Mariani (Eds.), Por uma análise automática do discurso: Uma introdução a obra de Michel Pêcheux. São Paulo: Editora da Unicamp.

Pereira, S. J. N., \& Ayrosa, E. A. T. (2012). Corpos consumidos: Cultura de consumo gay carioca. Organizações \& Sociedade, 19(61), 295-313.

Rocha, E., \& Rodrigues, J. C. (2012). Corpo e consumo: Roteiro de estudos e pesquisas. Rio de Janeiro: Editora PUC Rio.

Safatle, V. (2004). Destruição e reconfiguração do corpo na publicidade mundial dos anos 90. Comunicação Mídia e Consumo, 1(1), 33-51.

Sarfati, G. E. (2010). Princípios da análise do discurso. São Paulo: Ática.

Scaraboto, D., \& Fischer, E. (2013). Frustrated fatshionistas: An institutional theory perspective on consumer quests for greater choice in mainstream markets. Journal of Consumer Research, S183-S206.

Schau, H. J. (2000). Consumer imagination, identity and self-expression. Advances in Consumer Research, $27,50-56$.

Schouten, J. W. (1991). Selves in transition: Symbolic consumption in personal rites of passage and identity reconstruction. Journal of Consumer Research, 17 (Março), 412-425.

Schouten, J. W., \& McAlexander, J. H. (1995). Subcultures of consumption: An ethnography of the new bikers. Journal of Consumer Research, 22 (June), 43-61. 
Scott, L. M. (1994). Images in advertising: The need for a theory of visual rhetoric. Journal of Consumer Research, 21(September), 252-272.

Slater, D. (2001). Cultura do consumo \& modernidade. São Paulo: Nobel.

Taylor, C. (1992). Sources of the self: The making of the modern identity. Cambridge: Cambridge University Press.

Thompson, C. J. (2014). The politics of consumer identity work. Journal of Consumer Research, 40(5), S155-S157.

Thompson, C. J., \& Hirschman, E. C. (1995). Understanding the socialized body: A poststructuralist analysis of consumer's self-conceptions, body images and self-care products. Journal of Consumer Research, 22 (Setembro), 139-164.

Thompson, C. J., \& Holt, D. B. (2004). How do man grab the phallus? Journal of Consumer Culture, 4(3), 313-338.

Vergara, S. C. (2008). Métodos de pesquisa em administração. São Paulo: ATLAS.

Zanette, M. C., \& Brito, E. P. Z. (2018). Fashionable subjects and complicity resistance: Power, subjectification, and bounded resistance in the context of plus-size consumers. Consumption Markets \& Culture, 1-20.

\section{Acknowledgements}

We would like to acknowledge CNPq for the financial support to conduct this research.

\section{About the Authors}

\section{Tânia Maria de Oliveira Almeida Gouveia}

Professor at the Graduate Program in Accounting (Programa de Pós-Graduação em Ciências Contábeis) and the Gradute Program in Controlling and Public Management (Programa de Pós-Graduação em Controladoria e Gestão Pública), School of Administration and Finance, Rio de Janeiro State University (Faculdade de Administração e Finanças da Universidade Federal do Rio de Janeiro).PhD in Administration by Fundação Getúlio Vargas. Email: almeida.tania@globo.com ORCID: 0000-0002-8231-9714

\section{Eduardo André Teixeira Ayrosa}

Professor at the Graduate Program of Administration, Universidade Positivo. PhD in Administration by London Business School (University of London). Email: eduardo.ayrosa@up.edu.br. ORCID: 0000-0002-9833-3756 